\title{
OPTIMIZATION OF BIODIESEL PRODUCTION FROM GOAT TALLOW USING ALKALINE CATALYSTS AND COMBINING THEM WITH DIESEL
}

\author{
Hossein Esmaeili1, *, Rauf Foroutan ${ }^{1}$
}

https://doi.org/10.23939/chcht12.01.120

\begin{abstract}
In this research biodiesel is produced from goat tallow in the presence of homogenous catalysts such as $\mathrm{KOH}$ and $\mathrm{NaOH}$ using trans-esterification process. For this purpose, effect of several parameters such as temperature, reaction time, methanol to oil ratio, type and concentration of a catalyst has been investigated. The results showed that the maximum biodiesel yield (96 and $98 \%$ ) was obtained using $\mathrm{NaOH}$ and $\mathrm{KOH}$, respectively, and optimal conditions were determined. Also, to improve some properties of biodiesel, biodiesel was mixed with diesel at different ratio (B5-B100) and their properties such as flash point, cloud point, pour point, viscosity and density were measured. It was found that the properties of produced biodiesel is in the range of standard and can be used as a biofuel.
\end{abstract}

Keywords: biodiesel, diesel, homogeneous catalyst, trans-esterification process.

\section{Introduction}

Nowadays, most attention is focused on different energy resources and it should be mentioned that nonrenewable natural resources at global scale are limited. These resources are totally restricted and cannot be reconstructed in a short period of time while $85 \%$ of global consumption is provided by fossil fuels and nonrenewable energy sources [1]. With increasing demand for energy and stringent environmental rules and also concern about global warming due to industrial developments, researchers are looking for alternative and renewable energy sources instead of fossil fuels to overcome the challenges of fossil fuel combustion problems in near future [2,3]. Biodiesel, is a renewable energy source which is a suitable alternative for fossil fuels as it has less sulfur content, carbon-free, renewable [4], non-toxic and

\footnotetext{
${ }^{1}$ Department of Chemical Engineering, Bushehr Branch, Islamic Azad University, Bushehr, Iran

*esmaeili.hossein@gmail.com

(C) Esmaeli H., Foroutan R., 2018
}

biodegradable [5]. Biodiesel is a clean fuel which can be applied with specific ratios like B5 and B20 in a mixture with diesel without change or modification of the engine. However, the volume ratio of the biodiesel in the mixture with diesel would affect the engine performance and exhaust profile. The results have shown that increasing biodiesel ratio will result in the increase in nitrogen oxides and fuel consumption, but the decrease of greenhouse gas emissions, particulate matter, carbon monoxide and hydrocarbon [6]. Besides, high oxygen content within the structure of biodiesel results in complete combustion within the engine [7]. Biodiesel or methyl ester is a fuel fatty acid that is produced from catalytic transesterification reaction between triglycerides of vegetable oils or animal fats and methanol [8]. It is estimated that production costs of biodiesels are about 1.5-2 times higher than diesel fuels, mainly due to high costs of initial feed; because initial feed makes about $75-80 \%$ of total costs [9]. Therefore, for economic feasibility of biodiesel production, wastes of frying oil, beef fat, pork fat or fat tannery waste [5], wastes of edible oils and animal fats [10] are used as low-cost initial feed in order to minimize total cost.

There are various methods for production of biodiesel from vegetable oil and animal fat such as direct utilization of vegetable oil or blending it with diesel fuel, micro-emulsion method, method of pyrolysis and transesterification method [11]. Biodiesel production with trans-esterification method and in the presence of homogeneous catalysts like sodium monoxide, sodium or potassium hydroxide is a common approach, but a catalyst recovery is very difficult as it dissolves in methanol and glycerol mixture [12]. In addition, using homogeneous catalysts is accompanied by issues like sewage water and emulsion production during separation and catalyst purification. Therefore, these parameters can reduce production efficiency and increase operational costs [4].

The objective of present study is to produce biodiesel from goat tallow using homogeneous catalysts like $\mathrm{KOH}$ and $\mathrm{NaOH}$ and investigate different parameters on a production process. To do so, various parameters 
were studied; parameters like temperature, reaction time, oil to methanol ratio, type and concentration of catalyst and optimal conditions were determined. Then, properties of produced biodiesel improved by blending it with petroleum diesel at different proportions and some properties (including flash point, pour point, cloud point, viscosity, density and cetane number) were identified according to ASTM D6751.

\section{Experimental}

\subsection{M aterials}

Goat tallow was gathered from local slaughterhouses and stored at plastic pockets at $269 \mathrm{~K}$ after washing and removing meat pieces. Methanol $(99.5 \%)$, sodium sulfate (99-100\%), sodium and potassium hydroxide were prepared from Merck Company. Diesel as a control sample was prepared from BushehrDiesel stations.

\subsection{Extracting Oil from Goat Tallow}

After washing the sample, $500 \mathrm{~g}$ of goat tallow were placed into $1000 \mathrm{ml}$ Beaker, $10 \mathrm{ml}$ of distilled water were added in order to prevent its burning and the mixture was put on heater at $373 \mathrm{~K}$ for $2 \mathrm{~h}$ to melt the tallow and evaporate water content within the oil content. Produced oil was cooled down completely by placing under the hood at ambient temperature for $2 \mathrm{~h}$. After removal of unmelted materials and filtering the oil, it was poured in a polyethylene plastic bottle and stored at ambient temperature. This oil was used as an initial feed for biodiesel production.

\subsection{Determining the Components of Fatty Acids of Goat Tallow}

The components of oil fatty acid extracted from goat tallow were determined using Gas Chromatography (GC). The GC model was Varian cp-3800 equipped with FID detector and $30 \mathrm{~m}$ capillary column under optimal conditions, especially for fatty acids investigations. Helium was used as a carrier gas. The components of fatty acid extracted from goat tallow are reported in Table 1.

\subsection{Optimal Parameters and Biodiesel Production}

In this study, the effect of different parameters in biodiesel production such as reaction temperature, reaction time, the amount and type of utilized catalyst and the proportion of methanol to oil were investigated and best results were selected as optimal conditions. Selection of optimal conditions was carried out while the changes of one parameter were examined as other parameters remained constant. Other parameters were also investigated in the same way. Reaction of oil with $1 \mathrm{wt} \%$ of potassium hydroxide and sodium hydroxide (based on oil weight) was performed at $323 \mathrm{~K}$ for $60 \mathrm{~min}, 500 \mathrm{rpm}$ mixer rate and different proportions of methanol with oil $(1: 3,1: 4,1: 5,1: 6$ and 1:9). After defining optimal condition for methanol to oil proportion for abovementioned catalysts, the reaction was performed at $323 \mathrm{~K}$ for $60 \mathrm{~min}, 500 \mathrm{rpm}$ mixing rate and different concentrations of catalysts $(0.5,0.75,1$ and $1.25 \mathrm{wt} \%)$. Afterwards, the effect of other parameters like temperature (303-353 K) and reaction time (30-180 min) were defined under previously determined optimal conditions.

In order to wash biodiesel, at first glycerol was separated from methyl ester phase (biodiesel) and then this phase was washed by double distilled water for a number of times at $343 \mathrm{~K}$ till the catalyst and methanol were separated from methyl ester phase. Afterwards, methyl ester was poured into the beaker and $2 \mathrm{~g}$ of sodium sulfate were added and mixed for 10 min till the water content of the product was adsorbed. After filtration, methyl ester phase (biodiesel) was retained in plastic containers made up of polyethylene terephthalate and stored at ambient temperature for evaluating the properties and composition of fuels derived from oil. In this study, all reactions repeated twice and carried out at atmosphere pressure and temperature was provided through the heater with magnetic stirrer model Yellow MAG HS 7. The efficiency of produced biodiesel for both cases of homogeneous and heterogeneous catalysts was determined by the following equation [13]:

\section{Efficiency $(\%)=[$ Weight of produced product $(\mathrm{g})] /$} [Weight of initial oil (g)]

\subsection{Blending Biodiesel with Diesel and Investigating its Properties}

Exploring and improving physical properties of produced biodiesel from goat tallow, different combinations of biodiesel with diesel (B5, B10, B20, B50, $\mathrm{B} 60$ and B80) were prepared and compared with pure biodiesel (B100). Samples are shown as BX where B represents biodiesel and $\mathrm{X}$ represents volume percentage of biodiesel blended with diesel. Mixtures were prepared at ambient temperature and the magnetic stirrer was applied to uniform the mixture. 
Components of fatty acids in goat tallow

\begin{tabular}{|c|c|c|c|}
\hline Percentage & Chemical formula of free fatty acids & Structure of free fatty acids & Free fatty acid composition \\
\hline 29.25 & $\mathrm{C}_{16} \mathrm{H}_{32} \mathrm{O}_{2}$ & $16: 0$ & Palmitic acid \\
\hline 6.62 & $\mathrm{C}_{18} \mathrm{H}_{36} \mathrm{O}_{2}$ & $18: 0$ & Stearic acid \\
\hline 45 & $\mathrm{C}_{18} \mathrm{H}_{34} \mathrm{O}_{2}$ & $18: 1$ & Oleic acid \\
\hline 13.9 & $\mathrm{C}_{18} \mathrm{H}_{32} \mathrm{O}_{2}$ & $18: 2$ & Linoleic acid \\
\hline 0.614 & $\mathrm{C}_{18} \mathrm{H}_{30} \mathrm{O}_{2}$ & $18: 3$ & Linolenic acid \\
\hline 0.6 & $\mathrm{C}_{14} \mathrm{H}_{28} \mathrm{O}_{2}$ & $14: 0$ & Myristic acid \\
\hline 0.06 & $\mathrm{C}_{12} \mathrm{H}_{24} \mathrm{O}_{2}$ & $12: 0$ & Lauric acid \\
\hline 0.05 & $\mathrm{C}_{20} \mathrm{H}_{40} \mathrm{O}_{2}$ & $20: 0$ & Arachidic acid \\
\hline
\end{tabular}

\subsection{Biodiesel Analysis and Blending Biodiesel with Commercial Fuel}

In order to identify the physical properties of pure biodiesel and biodiesel blended with fuel derived from oil, some properties were studied like density, kinematic viscosity, cloud point, pour point and flash point according to ASTM D6751. There has been no document reporting density and pour point of pure biodiesel and other fuel combinations according to ASTM. Other properties of biodiesel like kinematic viscosity, cloud point and flash point were measured based on ASTM D445, ASTM D2500 and ASTM D93, respectively. Flash point of pure biodiesel and other samples were measured by Automated Pensky-Martens closed cup, Apm-7 Tanaka Model made in Japan. Cloud point and pour point were also measured by Cloud Point Pour Point, Newlab 1300 Model made by Lin Tronic Switzerland. Kinematic viscosity was determined at 313 K using Kinematic Viscosity Bath Model K, Koehler 23377 equipped with a water bath.

\section{Results and Discussion}

\subsection{The effect of Methanol to Oil Ratio on Biodiesel Efficiency}

Biodiesel production can be done by transesterification and esterification reactions and both reactions are reversible [14]. In trans-esterification process, the amount of excess consumed methanol caused changes in the direction of the reaction progress and biodiesel production. Reaction stoichiometry showed that 3 moles of methyl ester (biodiesel) are produced if 1 mole of oil (tri-glyceride) is added to 3 moles of alcohol [15]. The effect of methanol to oil ratio on the efficiency of the biodiesel production using homogeneous catalysts is shown in Fig. 1. Experimental results revealed that increasing methanol to oil ratio from 1:3 up to 1:9 leads to the increase in biodiesel production efficiency, but no abrupt change in production efficiency was observed in higher ratios. High methanol content causes formation of methoxy on the surface of the catalyst which results in the change in equilibrium in the forward direction and increasing the efficiency of biodiesel production [16]. It should be also mentioned that increasing methanol ratio is not accompanied by a significant change in the efficiency of biodiesel production that is the result of glycerol solution within excess methanol in the reaction and its hard separation from methanol [17]. This, in turn, inhibits the reaction of methanol with the catalyst and reactant and alters the equilibrium in the opposite direction and reduces the amount of produced biodiesel.

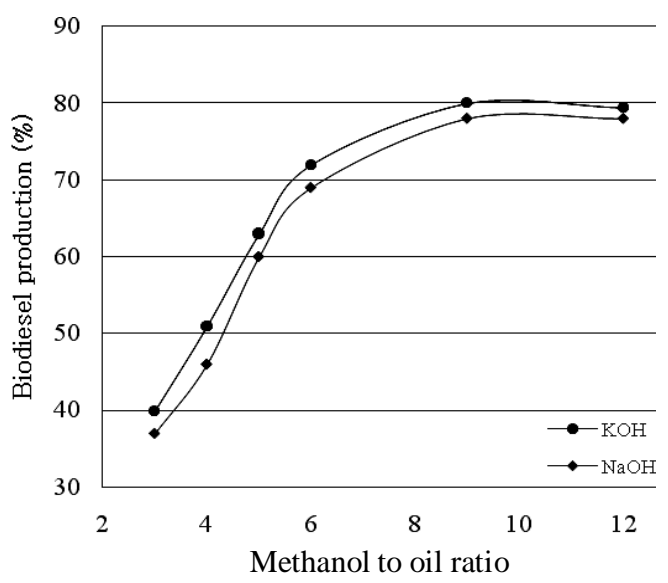

Fig. 1. Effect of methanol to oil ratio on biodiesel production. Conditions: temperature $323 \mathrm{~K}$; reaction time $60 \mathrm{~min}$; amount of catalyst $1 \mathrm{wt} \%$ and mixing rate $500 \mathrm{rpm}$

\subsection{Effect of Reaction time on the Efficiency of Biodiesel Production}

Reaction time is one of the important and effective parameters in the production and efficiency of biodiesel. This effect using homogeneous catalysts is shown in Fig. 
2. The results of experiments showed that increasing the reaction time was followed by the increase in the efficiency of biodiesel production and equilibrium time of trans-esterification reaction of the oil for both homogeneous catalysts was defined to be $120 \mathrm{~min}$. It is also noticeable that at biodiesel production with homogeneous catalysts, the efficiency of produced biodiesel decreases with time due to more saponification of fatty acids in the oil [18]. Maximum efficiency of biodiesel production at equilibrium time for $\mathrm{KOH}$ and $\mathrm{NaOH}$ as catalysts was reported as 90 and $88 \%$, respectively.

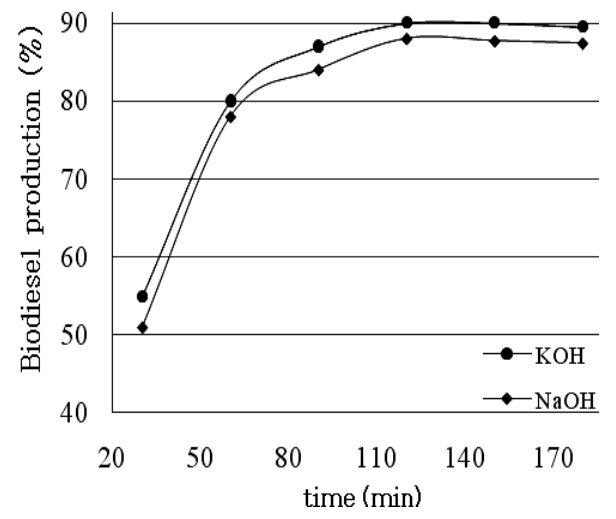

Fig. 2. Effect of time on biodiesel production.

Conditions: temperature $323 \mathrm{~K}$; methanol to oil ratio 1:9; amount of catalyst $1 \mathrm{wt} \%$ and mixing rate $500 \mathrm{rpm}$

\subsection{Effect of Catalyst Type and Amount}

The amount of the catalyst used within the process is another important parameter, because it can affect the reaction rate and causes hydrolysis and saponification [19]. In order to identify the effect of the catalyst amount on the efficiency of produced biodiesel, the influence of amount for both homogenous catalysts $(\mathrm{NaOH}$ and $\mathrm{KOH})$ was studied in the range of $0.25-1.5 \mathrm{wt} \%$. The results are shown in Fig. 3. Accordingly, at early stages, increasing the amount of catalysts is followed by the increase in biodiesel production efficiency. The optimum amount was found to be 1 and $0.75 \mathrm{wt} \%$ for $\mathrm{KOH}$ and $\mathrm{NaOH}$, respectively. Owing to trans-esterification process and alkaline environment, at low catalyst concentration higher amount of catalyst is required to reach equilibrium. Raising this amount leads to the decrease in biodiesel production that is the result of catalyst reaction with other reactants [20]. Besides, the decrease in the efficiency of biodiesel production because of the increase in the amount of catalyst can be dedicated to saponification [21] and conversion into a viscous solution [18].

\subsection{Effect of Reaction Temperature}

Effect of reaction temperature on biodiesel production using homogeneous catalysts is shown in Fig. 4.
This figure confirms that temperature increase in the range from 303 to $333 \mathrm{~K}$ increases the efficiency of biodiesel production, but higher temperatures cause the decrease in production efficiency. Different parameters influence biodiesel production such as methanol to oil ratio and reaction temperature. The results of previous studies showed that the increase in methanol content can move the equilibrium towards the products. Therefore, in order to prevent reverse reaction of trans-esterification, the higher amount of methanol is necessary. In addition, reaction temperature is an important parameter for biodiesel production and decrease of costs. As temperature exceeds $333 \mathrm{~K}$, some of the solvent (methanol) is evaporated without availability for the catalyst and oil that leads to the decrease in biodiesel production at higher temperatures [22]. In the present study, optimum temperature for biodiesel production for both catalysts was determined to be $333 \mathrm{~K}$ and maximum efficiency for $\mathrm{KOH}$ and $\mathrm{NaOH}$ at this temperature was 98 and $96 \%$, respectively.

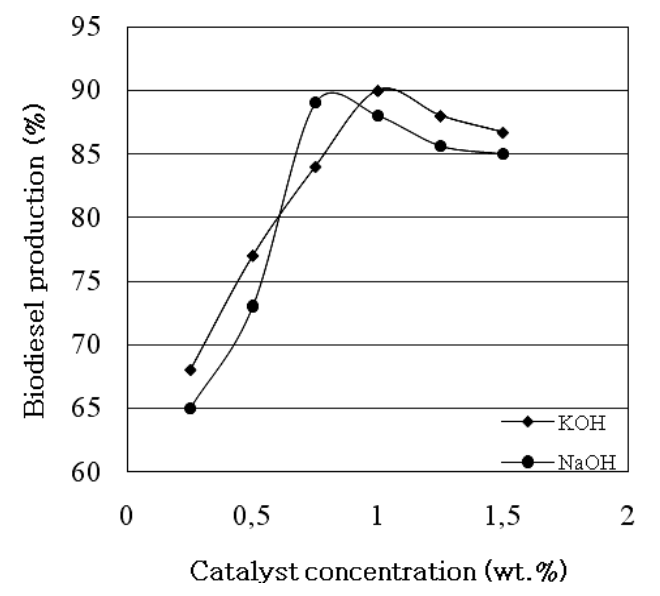

Fig. 3. Effect of catalyst concentration on biodiesel production. Conditions: temperature $323 \mathrm{~K}$; methanol to oil ratio 1:9; reaction time $120 \mathrm{~min}$ and mixing rate $500 \mathrm{rpm}$

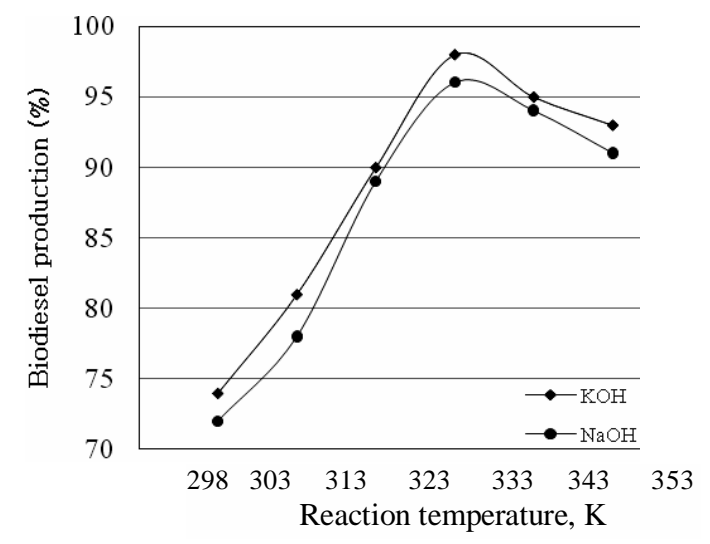

Fig. 4. Effect of temperature on biodiesel production. Conditions: methanol to oil ratio 1:9; amount of catalyst $1 \mathrm{wt} \%$ and $0.75 \mathrm{wt} \%$ for $\mathrm{KOH}$ and $\mathrm{NaOH}$, respectively; time $120 \mathrm{~min}$ and mixing rate $500 \mathrm{rpm}$ 


\subsection{Physical Properties of Pure Biodiesel and Biodiesel Blended with Diesel}

\subsubsection{Density}

Density is an important feature of fuel that directly affects the functionality of the engine. Some features like cetane number and the amount of produced heat are proportional to the density. Changes in the density of produced biodiesel applying homogeneous catalysts $(\mathrm{KOH}$ and $\mathrm{NaOH})$ blending with diesel is shown in Table 2. It is observed that fuel density increases as the proportion of biodiesel increases in the blended mixture while density of pure biodiesel for $\mathrm{KOH}$ and $\mathrm{NaOH}$ catalysts was 890 and $884 \mathrm{~kg} / \mathrm{m}^{3}$, respectively. This proportion is high in comparison with diesel fuel, but it is in the range of cited values according to EN 14214 biodiesel standard. Therefore, biodiesel combination with diesel of $5 \%$ composition is a suitable density, because the higher biodiesel content increases fuel density leading to a slow delivery of the fuel into the fuel injection system [23]. Altogether, increasing the proportion of biodiesel enhances the density of blended fuel as far as it is within the standard range of biodiesel.

\subsubsection{Kinematic viscosity}

Viscosity is an imperative parameter while using fuels; as it affects the quality of atomization and spray of the fuel. Viscosity plays an important role in lubrication of fuel injection system. At low viscosities, fuel cannot provide effective lubricity within an injection system. As a result, wearing and leakage occurs within the system. At high viscosities the injection system requires higher energy for injection and this leads to unsuitable distribution of the fuel within the cylinder, reduction in produced energy and higher amount of suspended particles and emissions in the exhaust [11]. The results of kinematic viscosity analysis of produced biodiesel from goat tallow with catalysts and in combination with diesel are represented in Table 2. As the proportion of biodiesel in the mixture with diesel increases, the viscosity of final fuel increases showing that higher energy is required to inject and transfer the fuel into the engine compared with diesel alone. Kinematic viscosity of pure biodiesel with $\mathrm{KOH}$ and $\mathrm{NaOH}$ was 5.5 and $5.6 \mathrm{~mm}^{2} / \mathrm{s}$, respectively, which is higher than diesel viscosity. Kinematic viscosity of diesel based on ASTM D6751 was reported in the range from 1.9 to $6 \mathrm{~mm}^{2} / \mathrm{s}$. The kinematic viscosity of produced biodiesel was in the accepted range.

\subsubsection{Flash point}

Fuel flash point is the temperature at which fire takes place if exposed to flame or spark. High flash point of biodiesel in comparison with oil derived fuel increases its safety while transportation, handling and storage [24]. Biodiesel flash point highly depends on residual methanol content; if methanol content in the biodiesel increases to $0.5 \%$, the flash point decreases by 52 degrees [25]. Therefore, methanol recovery from the biodiesel is a very important issue. Biodiesel flash point is reported as $403 \mathrm{~K}$ according to ASTM D6751. In Table 2, the effect of biodiesel percentage in combination with oil derived fuel on the flash point is shown. Fuel flash point increases as the proportion of biodiesel in the combination increases that are a safety issue in terms of storage and transportation. Therefore, the increase in the biodiesel content in the blended fuel is accompanied by improvement in fuel flash point. The flash points of biodiesel in this study with $\mathrm{KOH}$ and $\mathrm{NaOH}$ as catalysts were 453 and $457 \mathrm{~K}$, respectively.

Table 2

Properties of produced biodiesel from goat tallow using homogeneous catalysts KOH and $\mathrm{NaOH}$ and combining them with diesel at different ratios

\begin{tabular}{|c|c|c|c|c|c|c|c|c|c|}
\hline \multirow{2}{*}{ Property } & \multicolumn{7}{|c|}{ Biodiesel produced using $\mathrm{KOH}$ and combining them with diesel } & \multicolumn{2}{|c|}{ ASTM D6751-06 } \\
\hline & B5 & B10 & $\mathrm{B} 20$ & B50 & B60 & B80 & B100 & Limits & Units \\
\hline Density & 813 & 825 & 830 & 854 & 870 & 879 & 890 & - & $\mathrm{kg} / \mathrm{m}^{3}$ \\
\hline Kinematic viscosity & 2.4 & 3 & 3.7 & 4.5 & 4.8 & 5.1 & 5.5 & $1.9-6$ & $\mathrm{~mm}^{2} / \mathrm{s}$ \\
\hline Flash point & 343 & 345 & 357 & 388 & 395 & 413 & 453 & 403 & $\mathrm{~K}$ \\
\hline Cloud point & 268.5 & 269 & 272 & 274 & 276 & 277.2 & 281 & - & $\mathrm{K}$ \\
\hline Pour point & 243 & 241 & 257 & 264 & 267 & 272 & 275 & - & $\mathrm{K}$ \\
\hline \multirow{2}{*}{ Property } & \multicolumn{7}{|c|}{ Biodiesel produced using $\mathrm{NaOH}$ and combining them with diesel } & \multicolumn{2}{|c|}{ ASTM D6751-06 } \\
\hline & B5 & B10 & $\mathrm{B} 20$ & $\mathrm{~B} 50$ & B60 & $\mathrm{B} 80$ & B100 & Limits & Units \\
\hline Density & 819 & 823 & 827 & 850 & 869 & 876 & 884 & - & $\mathrm{kg} / \mathrm{m}^{3}$ \\
\hline Kinematic viscosity & 2.8 & 3.1 & 3.8 & 4.7 & 4.9 & 5.3 & 5.6 & $1.9-6$ & $\mathrm{~mm}^{2} / \mathrm{s}$ \\
\hline Flash point & 346 & 348 & 361 & 393 & 398 & 420 & 457 & 403 & $\mathrm{~K}$ \\
\hline Cloud point & 269.2 & 270 & 273 & 275.3 & 277 & 278 & 281.2 & - & $\mathrm{K}$ \\
\hline Pour point & 246 & 247 & 259 & 264 & 266 & 273 & 276 & - & $\mathrm{K}$ \\
\hline
\end{tabular}




\subsubsection{Cloud point and pour point}

Cloud point and pour point are two important parameters for fuel utilization at low temperatures. Cloud point is a temperature below which waxy appearance is observable in the fuel. Pour point is the minimum temperature that fuel can maintain its liquid and flow characteristic [26]. These parameters depend on the temperature and affect utilization of biodiesel at various climate and geographic conditions. In ASTM D6751, no limit for cloud point is determined and this value is identified according to various climate conditions in every region. But in some studies, this value has been reported for produced biodiesel based on EN ISO3016 with some variances with other references as 253-245 K [27]. The effect of combined biodiesel with diesel on the cloud point and pour point are shown in Table 2. These values prove that pure biodiesel cannot be used in glacial and winter conditions.

\section{Conclusions}

Oil derived fuels are stored underground and cannot be renewed as consumed. Due to the combustion of these fuels, harmful gases like $\mathrm{CO}_{2}, \mathrm{NO}_{\mathrm{x}}$ and $\mathrm{CO}$ are produced that cause changes in the temperature and global warming. In order to reduce the effect of greenhouse gases and global warming, comprehensive studies have been carried out to find the appropriate fuel to replace fossil fuels. Biodiesel is one of these new fuels which is environmentally friendly and is produced from different oil resources. In this study, goat tallow was used as the initial feed with homogeneous catalysts for biodiesel production. Such biodiesel produced from oil resources have various features compared with diesel. In order to improve the features of produced biodiesel, it was combined with different proportions of diesel and the features of this mixture were investigated according to ASTM D6751. The results revealed that increasing biodiesel percentage in the mixture reduces some qualities like cloud point, pour point, density and kinematic viscosity. But fuel flash point improved significantly and higher proportions of biodiesel in the blended fuel improved the safety in terms of storage and transportation. Therefore, considering air pollution and global warming and the fact that fossil fuels are not renewable, it can be concluded that biodiesel fuel is an appropriate replacement for fossil fuels and can be used purely or in combination with diesel in related engines.

\section{References}

[1] Lee S., Wong Y., Tan Y., Yew S.: Energ. Convers. Manage., 2015, 93, 282. https://doi.org/10.1016/j.enconman.2014.12.067 [2] Nascimento I., Cabanelas I., dos Santos J., Nascimento M.: Algal Res., 2015, 8, 53. https://doi.org/10.1016/j.algal.2015.01.001 [3] Palash S., Masjuki H., Kalam M., Atabani A.: Energ. Convers. Manage., 2015, 91, 149.

https://doi.org/10.1016/j.enconman.2014.12.009

[4] Xue B.-j., Luo J ,.Zhang F., Fang Z.: Energy, 2014, 68, 584. https://doi.org/10.1016/j.energy.2014.02.082

[5] Šánek L., Pecha J., Kolomazník K., Bařinová M.: Fuel, 2015, 148, 16. https://doi.org/10.1016/j.fuel.2015.01.084

[6] Wong P., Wong I., Vong C., Cheung C.: Renew. Energ., 2015, 74, 640. https://doi.org/10.1016/j.renene.2014.08.075

[7] Guldhe A., Singh B., Mutanda T. et al.: Renew. Sust. Energ. Rev., 2015, 41, 1447. https://doi.org/10.1016/j.rser.2014.09.035

[8] Yan B., Zhang Y., Chen G., Shan R.: Energ. Convers. Manage., 2016, 130, 156. https://doi.org/10.1016/j.enconman.2016.10.052

[9] Yin X., You Q., Ma H., Dai C.: Ultrason. Sonochem., 2015, 23, 53. https://doi.org/10.1016/j.ultsonch.2014.08.020

[10] Tan K., Lee K., Mohamed A.: Energy, 2011, 36, 2085. https://doi.org/10.1016/j.energy.2010.05.003

[11] Esmaeili H., Foroutan R., Asl M.: Advances in Bioresearch 2016, 7, 44. https://doi.org/10.15515/abr.0976-4585.7.1.4452

[12] Zhang F., Fang Z., Wang Y.-T.: Fuel, 2015, 150, 370. https://doi.org/10.1016/j.fuel.2015.02.032

[13] Charoenchaitrakool M., Thienmethangkoon J.: Fuel Process. Technol., 2011, 92, 112.

https://doi.org/10.1016/j.fuproc.2010.09.012

[14] Shu Q., Gao J., Nawaz Z., Liao Y.: Appl. Energ., 2010, 87, 2589. https://doi.org/10.1016/j.apenergy.2010.03.024

[15] Encinar J., González J., Pardal A.: Fuel Process. Technol., 2012, 103, 9. https://doi.org/10.1016/j.fuproc.2011.12.033

[16] Farooq M., Ramli A., Naeem A.: Renew. Energ., 2015, 76,

362. https://doi.org/10.1016/j.renene.2014.11.042

[17] Liu K., Wang R.: Petroleum \& Coal, 2013, 55, 68.

[18] Li Y., Qiu F., Yang D. et al.: Biomass Bioenerg., 2011, 35,

2787. https://doi.org/10.1016/j.biombioe.2011.03.009

[19] Li Y., Qiu F., Yang D. et al.: Food Bioprod. Process., 2012, 90, 135. https://doi.org/10.1016/j.fbp.2011.02.004

[20] Chen G., Shan R., Li S., Shi J.: Fuel, 2015, 153, 48. https://doi.org/10.1016/j.fuel.2015.02.109

[21] Vyas A., Verma J., Subrahmanyam N.: Adv. Chem. Eng. Sci., 2011, 1, 45. https://doi.org/10.4236/aces.2011.12008

[22] Feyzi M., Hassankhani A., Rafiee H.: Energ. Convers.

Manage., 2013, 71, 62.

https://doi.org/10.1016/j.enconman.2013.03.022

[23] Altuna Ş., Yaşarb F., Önerc C.: Int. J. Eng. Res. Develop., 2010, $2,2$.

[24] Alptekin E., Canakci M.: Fuel, 2011, 90, 2630.

https://doi.org/10.1016/j.fuel.2011.03.042

[25] Rabu R., Janajreh I., Honnery D.: Energ. Convers. Manage., 2013, 65, 764. https://doi.org/10.1016/j.enconman.2012.02.031

[26] Saydut A., Duz M., Kaya C.: Biores. Technol., 2008, 99, 6656. https://doi.org/10.1016/j.biortech.2007.11.063

[27] Diya'uddeen B., Aziz A., Daud W., Chakrabarti M.: Process Saf. Environ., 2012, 90, 164.

https://doi.org/10.1016/j.psep.2012.02.005

Received: May 29, 2017 / Revised: June 06, 2017 / Accepted: September 08, 2017 


\section{ОПТИМІЗАЦІЯ ВИРОБНИЦТВА БІОДИЗЕЛЮ З КОЗЯЧОГО ЖИРУ В ПРИСУТНОСТІ ЛУЖНИХ КАТАЛІЗАТОРІВ ТА ЙОГО КОМБІНУВАННЯ З ДИЗЕЛЬНИМ ПАЛИВОМ}

Анотація. 3 використанням процесу транс-естерифікачії отримано біодизель з козячого жиру в присутності гомогенних каталізаторів, таких як КОН та NaOH. Досліджено вплив таких параметрів як температура, час реакиії, відношення метанол/олива, тип і концентрація каталізатора. Встановлено, що максимальний вихід біодизелю (96 та 98 \%) був отриманий відповідно з $\mathrm{NaOH}$ та КОН, а також визначено оптимальні умови. Для поліпшення деяких властивостей біодизеля проведено його змішування з дизельним паливом $у$ різному співвідношенні (В5-В100) та визначено їх властивості, такі як температура спалаху, температура помутніння, температура застигання, в 'язкість і густина. Показано, щуо властивості отриманого біодизеля знаходяться в межсах стандартних величин та його можна використовувати як біопаливо.

Ключові слова: біодизель, дизельне паливо, гомогенний каталізатор, проиес транс-естерифікаиії. 